\title{
Spatial Decision Support Systems untuk Aplikasi Pengelolaan Database Penduduk Miskin Perkotaan
}

\author{
Fitri Imansyah*1 \\ *Program Studi Teknik Elektro, Jurusan Teknik Elektro, Fakultas Teknik, Universitas Tanjungpura \\ Jl. Prof. Dr. H. Hadari Nawawi, Bansir Laut, Kec. Pontianak Tenggara, Kota Pontianak, Kalimantan Barat 78124 \\ fitri.imansyaheee.untan.ac.id
}

\begin{abstract}
Abstrak
Penyalahgunaan atau penyelewengan dalam pelaksanaan program pengentasan kemiskinan tidak akan serta merta bisa hilang melalui sistem ini. Manfaat yang dapat diperoleh dari hasil penelitian ini antara lain: Berdasarkan hasil yang dikembangkan salah satunya berguna untuk proses pembaharuan (updating) data penduduk miskin dengan partisipasi aktif dari unsur pemerintahan terendah (kelurahan/desa) dan pemberdayaan pengurus RT/RW sebagai perpanjangan tangan pemerintah dengan melakukan survey secara berkala. Dengan pendekatan ini akan diperoleh data penduduk miskin yang dapat dipercaya dan dapat menekan biaya survey yang relatif mahal; Tersedia aplikasi yang mengelola data penduduk miskin dan program-program yang ditujukan kepada penduduk miskin sehingga pihak terkait dapat melakukan analisis berdasarkan data yang dimiliki untuk proses pengambilan keputusan, serta aplikasi pengelolaan database penduduk miskin yang dapat menjadi alat bantu pendukung pengambilan keputusan (decision support tools) mengelola data berdasarkan runut waktu (time series) berdasarkan tahun dengan demikian data yang tersedia dapat dimanfaatkan oleh pihak terkait atau stakeholder untuk melakukan evaluasi dan analisis profil kemiskinan kota dalam rangka evaluasi keberhasilan program pengentasan kemiskinan atau pembuatan rencana program pengentasan kemiskinan selanjutnya. Pengembangan Aplikasi SDSS ditujukan untuk memberikan kemudahan kepada pengguna (user) untuk melihat data profil penduduk miskin baik data spasial (peta lokasi tempat tinggal) maupun data atribut (data deskriptif tentang penduduk miskin dan program bantuan yang pernah diterimanya). Dengan aplikasi SDSS ini, pengguna tidak harus memiliki kemampuan untuk menggunakan perangkat lunak SIG seperti ArcView GIS, MapInfo, MapWindow, ILWIS, dan sebagainya.

Kata kunci: Pengelolaan database, penduduk miskin, decision support tools, pengentasan kemiskinan.
\end{abstract}

\section{Spatial Decision Support Systems for Database Management Applications for the Urban Poor}

\begin{abstract}
Misuse or abuse in the implementation of poverty alleviation programs will not necessarily disappear through this system. The benefits that can be obtained from the results of this study include: Based on the results developed, one of them is useful for the updating process of poor population data with active participation from the lowest elements of government (village) and empowerment of RT / RW administrators as an extension of the government with conduct regular surveys. With this approach, reliable data on the poor can be obtained and can reduce relatively expensive survey costs; There are applications that manage data on the poor and programs aimed at the poor so that related parties can carry out analysis based on the data they have for the decisionmaking process, as well as database management applications for the poor that can be decision support tools. managing data based on time series (time series) based on years so that the available data can be used by related parties or stakeholders to carry out evaluation and analysis of urban poverty profiles in order to evaluate the success of poverty alleviation programs or making plans for further poverty alleviation programs. The development of the SDSS application is intended to make it easy for users to view profile data for the poor, both spatial data (map of residence locations) and attribute data (descriptive data about the poor and assistance programs they have received). With this SDSS application, users do not have to have the ability to use GIS software such as ArcView GIS, MapInfo, MapWindow, ILWIS, and so on.
\end{abstract}

Keywords: Database management, poor people, decision support tools, poverty alleviation.

\section{Pendahuluan}

Pemetaan kemiskinan (poverty mapping) dimaksudkan untuk memasukkan unsur geografis yang berkorelasi dengan indikator kemiskinan berdasarkan analisis wilayah kecil (small area analysis) atau tingkat administratif yang lebih rendah. Pelibatan unsur pemerintahan terendah (lurah/kepala desa) maupun perpanjangan tangan 
pemerintah yaitu RT/RW diperlukan untuk proses penghimpunan dan perbaharuan data penduduk disamping fungsi pengawasannya. Dengan pendekatan ini data penduduk miskin dapat diperbaharui untuk jangka waktu yang relatif singkat tanpa melakukan survey dengan biaya yang besar dan validitas datanya dapat ditingkatkan karena data dihimpun oleh unsur terbawah yang memahami kondisi masyarakat setempat. Partisipasi masyarakat dapat ditingkatkan karena data penduduk miskin, keberadaan tempat tinggal, program apa saja yang sudah diperolehnya dapat diakses oleh masyarakat [1],[2],[3],[4]. Dengan mengetahui informasi tersebut diharapkan masyarakat yang mampu akan tumbuh rasa empati, kepedulian, dan keinginannya untuk membantu penduduk miskin khususnya yang berada di dekat tempat tinggalnya.

Sistem ini akan membuka peluang yang selebarlebarnya kepada masyarakat untuk turut aktif berpartisipasi mendata penduduk miskin dan ikut dalam pengawasannya dengan mengakses ke dalam sistem aplikasi. Pengurus RT/RW sebagai instrument di masyarakat dapat ditingkatkan peranannya sebagai perpanjangan tangan pemerintah untuk melakukan pendataan penduduk miskin secara regular sehingga akan diperoleh data terbaru, dapat dipercaya, dan biaya survey yang rendah.

Pendekatan spasial atau geografis yang akan digunakan dalam penelitian ini mempunyai kelebihan yaitu dapat menunjukkan lokasi keberadaan penduduk miskin secara tepat dengan representasi koordinat lintang dan bujur [5],[6],[7],[8]. Pengelolaan data penduduk miskin yang selama ini dilakukan masih berbasis data tabular mempunyai tingkat validitas yang rendah karena lokasi keberadaan penduduk miskin tidak ditampilkan dalam representasi peta tetapi berupa data deskriptif berupa alamat tempat tinggal. Data deskriptif berupa alamat tempat tinggal inilah yang rawan dimanipulasi.

Pendekatan spasial berupa representasi geografis keberadaan tempat tinggal penduduk miskin akan mudah untuk dipantau dan dievaluasi karena masyarakat disekitarnya dapat mengetahui apakah penduduk miskin tersebut benar-benar ada atau fiktif. Demikian pula dalam hal pendataan penduduk miskin, masyarakat dapat menyampaikan keberadaan penduduk miskin dilingkungannya dengan menunjuk langsung lokasi tempat tinggal penduduk miskin tersebut di dalam peta. Validitas data penduduk miskin dapat ditingkatkan dengan mengikutsertakan pengurus rukun tetangga/rukun warga (RT/RW) untuk melakukan pendataan. Pada akhirnya sistem ini akan menjadi pendukung pengambilan keputusan bagi pemerintah pusat/daerah untuk melaksanakan program pengentasan kemiskinan secara tepat sasaran.

Penelitian ini merupakan kegiatan inovatif dalam pengelolaan database penduduk miskin di perkotaan. Sebuah aplikasi akan dikembangkan untuk menangani pengelolaan database dengan cara yang lebih mudah, efisien, dan efektif. Model yang digunakan adalah model spasial yang mengelola data spasial dan data tabular secara terintegrasi. Aplikasi yang dikembangkan diarahkan sebagai salah satu instrumen bagi pemerintah dalam pengambilan keputusan terkait dengan program pengentasan kemiskinan bagi penduduk miskin kota.

Sebagai salah satu instrumen pendukung maka perlu disusun sistem yang mampu memberikan dukungan khususnya informasi bagi pelaksana program pengentasan kemiskinan dalam mengambil keputusan. Model spasial yang digunakan dalam kegiatan ini ditujukan untuk mendukung keputusan yang selanjutnya disebut dengan spatial decision support systems (SDSS). Namun demikian penyalahgunaan atau penyelewengan dalam pelaksanaan program pengentasan kemiskinan tidak akan serta merta bisa hilang melalui sistem ini. Kontribusi dari kegiatan ini berupa aplikasi yang mengelola data penduduk miskin dan program-program yang ditujukan kepadanya sehingga berbagai pihak dapat melakukan pengawasan secara langsung, hal ini secara tidak langsung akan menekan tingkat penyelewengan dari oknum yang tidak bertanggung jawab.

Pemetaan kemiskinan dalam penelitian ini merupakan langkah untuk merelasikan data penduduk miskin (sebagai data atribut) dengan lokasi tempat tinggalnya (sebagai data spasial) untuk dapat dianalisis secara spasial dan mendapatkan profil yang lebih lengkap dari penduduk miskin. Pemetaan dilakukan untuk wilayah kecil (kelurahan/desa) namun dapat pula dilakukan analisis berdasarkan agregasi wilayah yang lebih besar (kecamatan, kota, atau propinsi) untuk mendukung pengambilan keputusan dalam perencanaan dan pelaksanaan program pengentasan kemiskinan [9],[10],[11].

Pendataan penduduk miskin dapat dibedakan dalam 2 (dua) kondisi yaitu [12],[13]:

a. Penduduk miskin kota yang benar-benar berdomisili di kota tersebut (dalam hal ini Kota Ketapang) dan memiliki kartu tanda penduduk (KTP) setempat. Pengurus RT/RW sebagai perpanjangan tangan pemerintah yang mengetahui secara rinci kondisi masyarakat dapat melakukan pendataan penduduk miskin diwilayahnya secara lebih detil.

b. Penduduk miskin kota yang domisilinya di luar kota namun bertempat tinggal sementara dan berpindah, misalnya di lahan kosong atau ditepian bantaran sungai di dalam Kota Ketapang. Pada kondisi ini pendataan akan menjadi sulit jika harus dilakukan oleh Pengurus RT/RW. Kemungkinan di wilayah tersebut tidak terdapat pemukiman atau jauh dari pemukiman penduduk sehingga pengurus RT/RW tidak dapat menjangkau penduduk miskin karena bukan berada di wilayahnya.

Dalam penelitian ini, keluaran yang dihasilkan tidak diarahkan untuk menyelesaikan semua faktor yang mempengaruhi berhasil tidaknya program pengentasan kemiskinan tetapi sebagai instrumen pendukung ditingkat pelaksana program pengentasan kemiskinan. Aplikasi dapat dijadikan salah satu instrumen bagi pemerintah atau stakeholder dalam pengambilan keputusan terkait dengan program pengentasan kemiskinan bagi penduduk miskin kota, khususnya dalam dukungan ketersediaan 
data/informasi penduduk miskin. Tujuan penelitian ini adalah:

1. Mengembangkan sebuah pengelolaan database penduduk miskin kota kemiskinan dengan pendekatan sistem informasi geografis.

2. Menghasilkan perangkat lunak aplikasi pengelolaan database penduduk miskin yang dapat menjadi alat bantu pendukung pengambilan keputusan (decision support tools) dalam penelitian pengentasan kemiskinan.

Berdasarkan hal-hal di atas dikembangkan suatu sistem yang mampu memberikan dukungan khususnya informasi spasial (pemetaan) bagi pelaksana program pengentasan kemiskinan dalam mengambil keputusan. Model spasial yang digunakan dalam penelitian ini ditujukan untuk mendukung keputusan yang selanjutnya disebut dengan spatial decision support systems (SDSS) [14],[15]. Fitur data spasial yang digunakan adalah titik (point) yang menunjukkan rumah atau tempat tinggal penduduk miskin dengan demikian sistem ini akan mendukung program pengentasan kemiskinan pada tingkat teknis di lapangan.

Dengan fitur titik sebagai representasi tempat tinggal penduduk miskin akan diketahui secara tepat keberadaan penduduk miskin yang menjadi sasaran program, selain itu masyarat baik secara perorangan atau melalui lembaga kemasyarakatan seperti RT/RW akan dapat melakukan pengawasan terhadap upaya-upaya penyimpangan atau manipulasi data penduduk miskin. Penduduk miskin yang belum terdata dapat dimasukkan atau diusulkan oleh RT/RW ke Kepala Kelurahan untuk selanjutnya data dikelola melalui sistem yang telah dikembangkan dalam penelitian ini.

\section{Metode Penelitian}

Secara skematik, penerapan metodologi yang dipilih diperlihatkan pada Gambar 1 sebagai suatu hubungan dari beberapa subsistem. Studi literatur dan survey diterapkan pada blok Data Input, sedangkan prototyping diterapkan pada blok Data Management dan Manipulation dan Data Ouput.

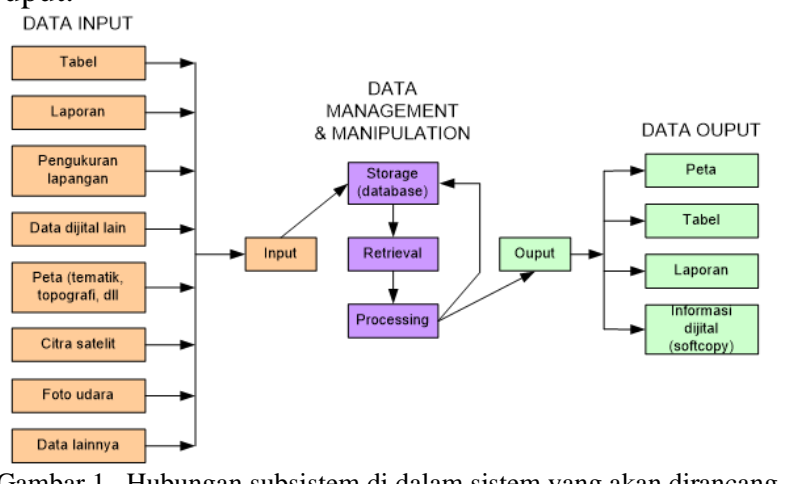

Penelitian ini dibagi dalam dua kegiatan utama yaitu analisis spasial peta penduduk miskin dan pengembangan aplikasi sistem informasi pemetaan penduduk miskin. Metode analisis dapat dilihat pada Gambar 2.

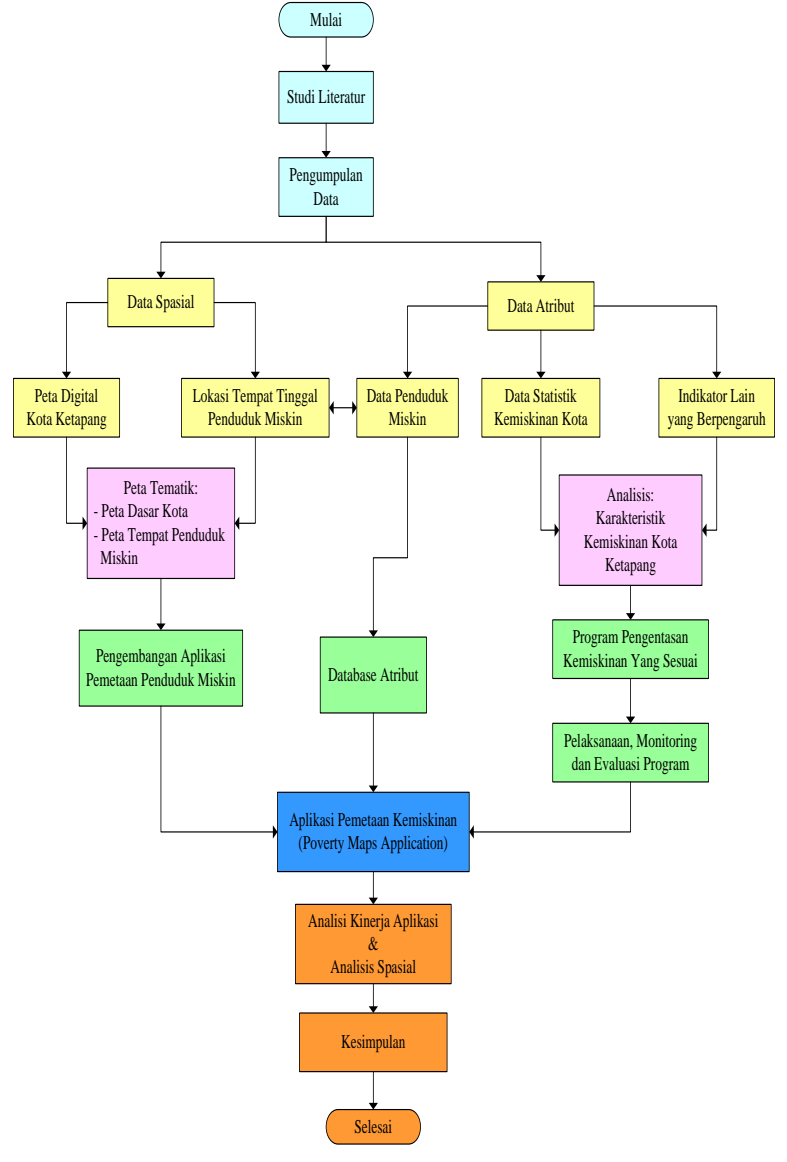

Gambar 2. Diagram alir penelitian

Oleh karena itu metode analisis yang digunakan juga dibedakan atas dua kegiatan tersebut, yaitu:

1) Analisis Small Area: Analisis "small area" merupakan teknik analisis secara statistik yang dikombinasikan dengan data survey dan data sensus untuk memprediksi tingkat kesejahteraan atau indikator lain yang dipisahkan berdasar unit geografis seperti kota atau pedesaan [4]. Dalam penelitian ini analsis "small area" dilakukan pada Kelurahan Tengah, Kauman, Desa Paya Kumang dan Banjar sebagai sampel.

2) Black box testing: Black box testing merupakan salah satu teknik pengujian perangkat lunak yang hanya terfokus pada fungsi input/output data tanpa memperhatikan proses internal yang terjadi di dalam program. Umumnya dilakukan dengan memasukkan nilai yang mudah (easy values), nilai ekstrim (extreme values), nilai tidak dibenarkan (illegal values), dan nilai yang masuk akal (realistic values) [16], [17].

Pengembangan aplikasi ini terdiri dari 4 (empat) tahapan utama yaitu: a) analisis kondisi saat ini (existing condition analysist), b) analisis kebutuhan informasi (berisi deskripsi sistem yang dirancang), c) perancangan aplikasi, dan d) pengujian aplikasi.

\section{A. Existing Condition Analysist}

Sistem berjalan yang diamati adalah proses pendataan penduduk miskin atau keluarga miskin dan proses pemberian bantuan yaitu Program RASKIN. Proses 
pendataan penduduk miskin yang dilakukan saat ini dapat dilihat pada Gambar 3.

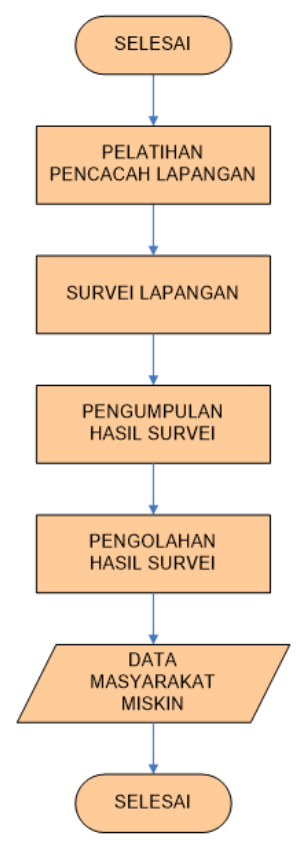

Gambar 3. Diagram alir pendataan masyarakat miskin

\section{B. Analisis Kebutuhan Informasi (Deskripsi Rancangan Sistem)}

Kelurahan sebagai unsur pemerintahan terbawah yang berhubungan langsung dengan masyarakat selayaknya memiliki dan menggunakan aplikasi sistem informasi geografis yang memiliki fungsi untuk memetakan rumah tangga miskin dan mengelola program bantuan yang sudah diberikan. Dengan informasi tersebut dapat dianalisis lebih lanjut ciri-ciri kemiskinan seorang penduduk dan selanjutnya pembuatan program pengentasan kemiskinan dapat dirancang sesuai kebutuhan penduduk miskin tersebut.

Pada aplikasi ini, daerah kelurahan direpresentasikan sebagai polygon, kemudian jalan direpresentasikan dengan line, dan lokasi tempat tinggal penduduk miskin ditunjukkan dengan point. Aplikasi ini memiliki fitur-fitur dimana pengguna dapat menambahkan jalan baru, mengubah atribut dan menghapus jalan yang sudah ada, menambahkan point baru, merelasikan point dengan data penduduk miskin dan menghapus point yang sudah ada.

Pengguna dapat melihat peta dengan tingkat perbesaran yang dapat disesuaikan, serta melakukan pencarian jalan pada peta. Hasil pencarian ditampilkan dalam suatu daftar. Pengguna dapat meng-klik nama jalan yang sesuai, dan sistem secara otomatis akan menyorot jalan tersebut. Pengguna dapat menyorot point untuk mengetahui nomor pengenal (No. ID) lokasi penduduk miskin.

Jika point sudah direlasikan dengan data penduduk miskin, pengguna dapat meng-klik point tersebut untuk mengetahui data detail tentang rumah tangga miskin yang ditunjukkan oleh point tersebut. Pengguna juga dapat melihat rekaman bantuan yang pernah diterima oleh rumah tangga miskin tersebut. Pengguna dapat melihat persebaran point pada peta, dan mengukur jarak maupun luas daerah pada peta. Pengguna dapat meng-ekspor peta ke dalam bentuk gambar tipe vektor (*.emf).

Pengguna dapat mengolah dan melihat data penduduk miskin, data program bantuan, rekaman bantuan yang diterima rumah tangga miskin dan meng-ekspor data-data tersebut ke Microsoft Office Excel. Data-data yang telah di-ekspor dapat diolah lebih lanjut sesuai dengan keperluan pengguna.

Untuk keperluan analisis secara spasial, aplikasi dapat menunjukkan data historis program bantuan atau program pengentasan kemiskinan yang pernah diterima atau yang belum pernah diterima oleh penduduk miskin, data ditampilkan secara spasial berdasarkan tempat tinggal penduduk miskin. Dengan fitur ini data hasil analisis dan menjadi sistem pendukung pengambilan keputusan (decision support systems).

\section{Metode Perancangan}

Dalam melakukan perancangan sistem, terdapat tahapan-tahapan yang dilakukan dalam proses perancangan yaitu:

1. Perancangan Basis Data. Terdiri dari perancangan Entity Relationship Diagram (ERD), spesifikasi tabel basis data dan diagram hubungan antartabel.

2. Perancangan Diagram Arus Data. Terdiri dari perancangan diagram konteks sistem, diagram overview sistem dan diagram rinci sistem.

3. Perancangan Antarmuka Sistem, yaitu perancangan antarmuka untuk administrator.

\section{Perancangan Basis Data}

Perancangan basis data ini meliputi 3 (tiga) kegiatan yaitu:

1. Perancangan Entity Relationship Diagram (ERD), berisikan hubungan entitas-entitas dalam sistem, yaitu masyarakat miskin (rumah tangga miskin), program bantuan. foto, video.

2. Pembuatan spesifikasi tabel basis data, berisikan spesifikasi dari tabel-tabel yang dipergunakan dalam perancangan sistem yaitu tabel dfoto, dmiskin, dprogram, dproperti dan dterima.

3. Pembuatan diagram hubungan antartabel, merupakan gambaran hubungan antar tabel yang dipergunakan dalam sistem.

\section{E. Perancangan Entity Relationship Diagram}

Aplikasi dirancang menggunakan motode ERD, dalam sistem ini terdapat 7 (tujuh) buah entitas yaitu a) penduduk miskin/rumah tangga miskin, b) program pengentasan kemiskinan, c) catatan penerima bantuan, d) foto penduduk/rumah tangga miskin, e) video situasi lingkungan di kelurahan/desa, f) kelurahan/desa, dan g) lokasi tempat tinggal penduduk/rumah tangga miskin. Hubungan masing-masing entitas direpresentasikan dalam diagram hubungan entitas (ERD) sebagaimana Gambar 4.

Enterprise rule dalam rancangan ini dapat dijelaskan sebagai berikut:

1. Satu rumah tangga miskin hanya memiliki satu lokasi tempat tinggal berdasarkan kelurahan atau desa.

2. Satu rumah tangga miskin dapat memiliki satu atau lebih dokumentasi foto sebagai pelengkap profilnya. 
3. Satu wilayah kelurahan/desa dapat memiliki lebih dari satu dokumentasi video yang menggambarkan situasi lingkungan di kelurahan/desa tersebut.

4. Banyak rumah tangga miskin dapat menerima banyak program pengentasan kemiskinan.

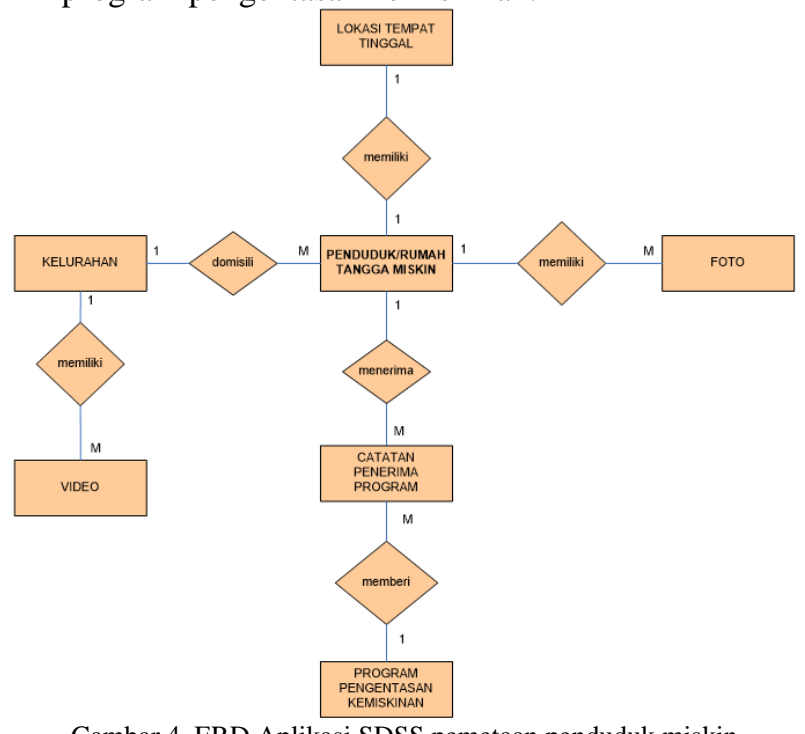

Gambar 4. ERD Aplikasi SDSS pemetaan penduduk miskin

\section{F. Spesifikasi Tabel Basis Data}

Tabel basis data diperoleh dari hasil perancangan ERD, berdasarkan rancangan ERD diperoleh 5 (lima) buah tabel utama dan 1 (satu) tabel pendukung, sebagaimana ditampilkan pada Tabel I.

TABEL I

DAFTAR TABEL BASIS DATA

\begin{tabular}{|c|c|c|}
\hline Nama Tabel & $\begin{array}{l}\text { Nama } \\
\text { file }\end{array}$ & Keterangan \\
\hline $\begin{array}{l}\text { Penduduk } \\
\text { Miskin/Rumah } \\
\text { Tangga Miskin }\end{array}$ & dmiskin & $\begin{array}{l}\text { Tabel basis data } \\
\text { masyarakat/rumah tangga miskin }\end{array}$ \\
\hline $\begin{array}{l}\text { Foto Profil } \\
\text { Penduduk Miskin }\end{array}$ & dfoto & $\begin{array}{l}\text { Tabel basis data foto masyarakat } \\
\text { miskin }\end{array}$ \\
\hline $\begin{array}{l}\text { Program } \\
\text { Pengentasan } \\
\text { Kemiskinan }\end{array}$ & dprogram & $\begin{array}{l}\text { Tabel basis data program } \\
\text { bantuan masyarakat miskin }\end{array}$ \\
\hline $\begin{array}{l}\text { Catatan Penerima } \\
\text { Program }\end{array}$ & dterima & $\begin{array}{l}\text { Tabel basis data penerima } \\
\text { bantuan }\end{array}$ \\
\hline $\begin{array}{l}\text { Pengaturan } \\
\text { Aplikasi }\end{array}$ & dproperti & $\begin{array}{l}\text { Tabel basis data pengaturan } \\
\text { aplikasi }\end{array}$ \\
\hline $\begin{array}{l}\text { Lokasi Tempat } \\
\text { Tinggal } \\
\text { Penduduk/RT } \\
\text { Miskin }\end{array}$ & spasial & $\begin{array}{l}\text { Tabel basis data spasial dengan } \\
\text { format dbf milik ArcView GIS } \\
\text { 3.x. File ini berelasi dengan } \\
\text { file .shp. }\end{array}$ \\
\hline $\begin{array}{l}\text { Video Profil } \\
\text { Kemiskinan per } \\
\text { Kelurahan }\end{array}$ & dvideo & $\begin{array}{l}\text { Tabel basis data video kondisi } \\
\text { lingkungan disekitar tempat } \\
\text { tinggal penduduk miskin di } \\
\text { setiap kelurahan }\end{array}$ \\
\hline Kelurahan & dkelurahan & Tabel basis data kelurahan \\
\hline Tabel statistik & dstatistik & $\begin{array}{l}\text { Tabel bantu atau table sementara } \\
\text { untuk keperluan analisis }\end{array}$ \\
\hline
\end{tabular}

\section{G. Diagram Hubungan Antar Tabel}

Diagram hubungan antar tabel merupakan gambaran hubungan antar tabel yang dipergunakan dalam perancangan sistem sebagaimana diperlihatkan Gambar 5.

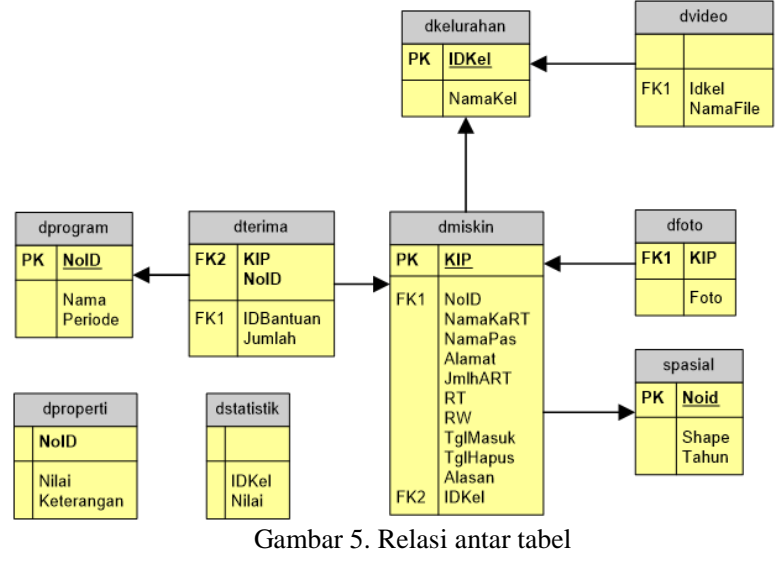

H. Perancangan Diagram Arus Data (DAD)

Diagram arus data merupakan gambaran umum mengenai prosedur sistem yang akan dirancang. Diagram arus data ini merupakan model dari sistem informasi geografis pemetaan masyarakat miskin, untuk menggambarkan pembagian sistem ke modul yang lebih kecil. Diagram arus data menampilkan kegiatan sistem lengkap dengan komponen-komponen yang menunjukkan secara tegas file-file yang dipakai, unsur sumber atau tujuan data, serta arus data dari satu proses ke proses lainnya.

\section{Diagram Konteks Sistem}

Diagram konteks adalah diagram yang memberikan gambaran seluruh proses terhadap seluruh masukan keluaran sistem yang dimaksudkan untuk menggambarkan sistem yang sedang berjalan, mengidentifikasikan awal dan akhir data yang masuk dan keluar sistem. Gambar 6 berikut akan lebih memperjelas aplikasi SDSS pemetaan masyarakat miskin.

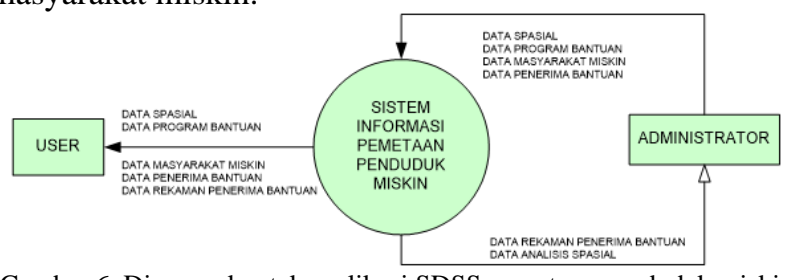

Gambar 6. Diagram konteks aplikasi SDSS pemetaan penduduk miskin

\section{J. Diagram Overview Sistem}

Diagram overview adalah diagram yang menggambarkan proses dari diagram arus data. Diagram overview memberikan pandangan secara menyeluruh mengenai sistem yang terdapat di kelurahan, yang menunjukkan tentang proses yang ada, arus data, dan entitas-entitas yang terkait. Diagram overview diperlihatkan pada Gambar 7, untuk external interactor USER tidak digambarkan karena aliran data yang menuju USER pada dasarnya sama dengan aliran data yang menuju ADMINISTRATOR.

\section{K. Diagram Rinci Sistem}

Diagram rinci menguraikan lebih lanjut mengenai urutan proses dari diagram overview, yang memperlihatkan arus data masuk dan arus data keluar. Berdasarkan diagram overview di atas, maka terdapat 4 buah diagram rinci sebagai berikut. 
1. Proses 1.0 Manajemen Peta adalah proses manajemen data yang berhubungan dengan peta. Proses ini terbagi lagi menjadi 9 proses (modul), secara skematik diagram rinci Proses 1.0 diperlihatkan pada Gambar 8.

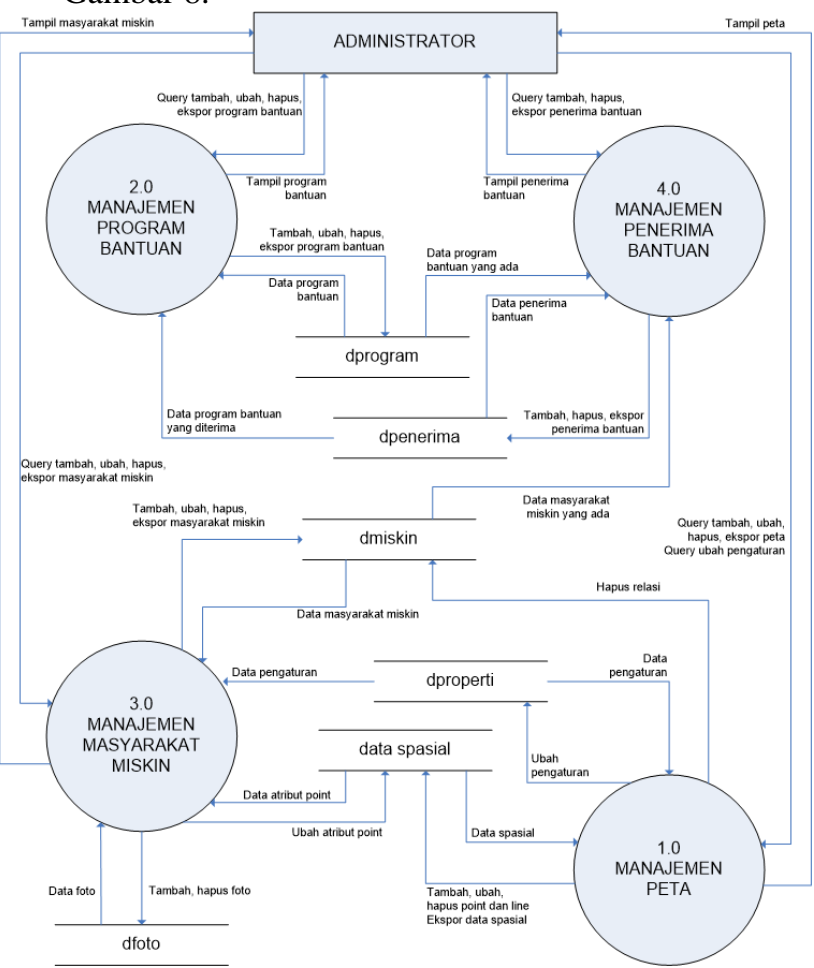

Gambar 7. Diagram overview aplikasi pemetaan penduduk miskin

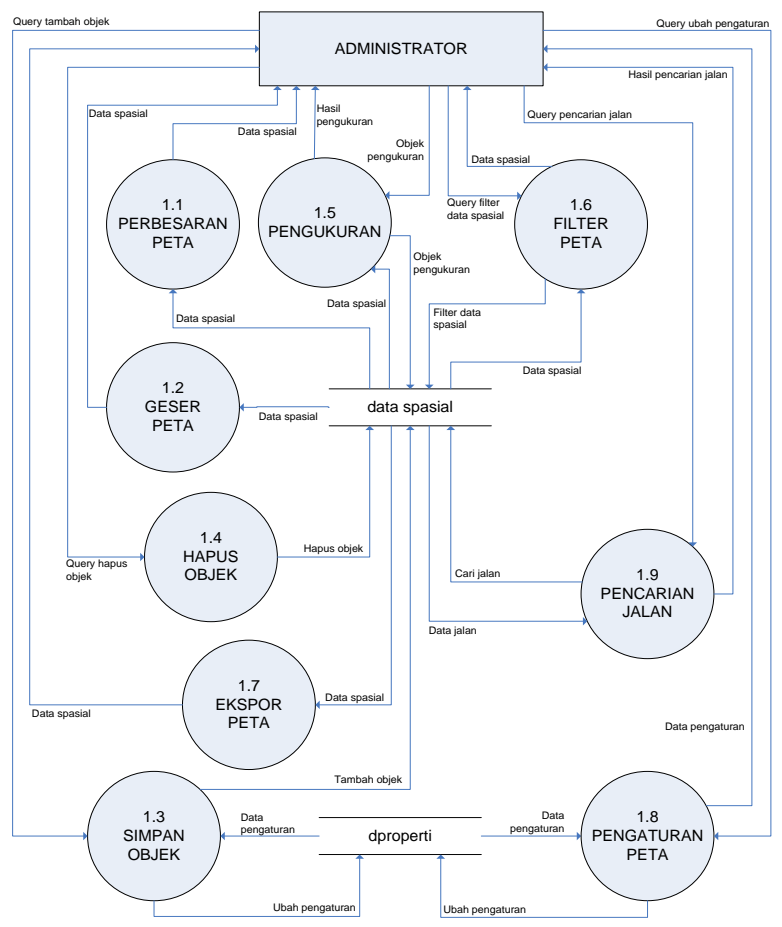

Gambar 8. Diagram rinci proses 1.0 manajemen peta

2. Proses 2.0 adalah proses manajemen program pengentasan kemiskinan. Proses ini terbagi lagi menjadi 4 proses, diagram rinci Proses 2.0 diperlihatkan pada Gambar 9.

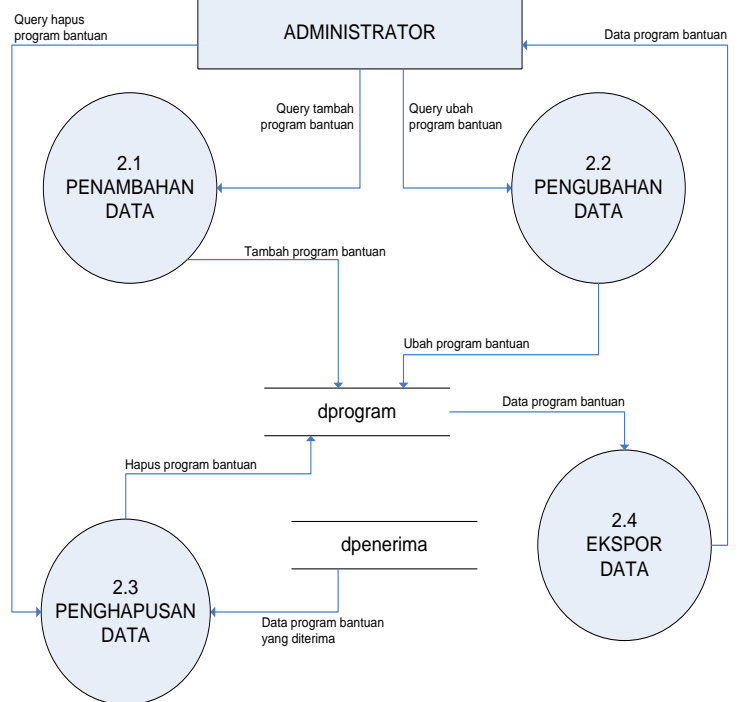

Gambar 9. Diagram rinci proses 2.0 manajemen program pengentasan kemiskinan

3. Proses 3.0 adalah proses manajemen masyarakat miskin. Proses ini terbagi lagi menjadi 7 proses, diagram rinci Proses 3.0 diperlihatkan pada Gambar 10 .

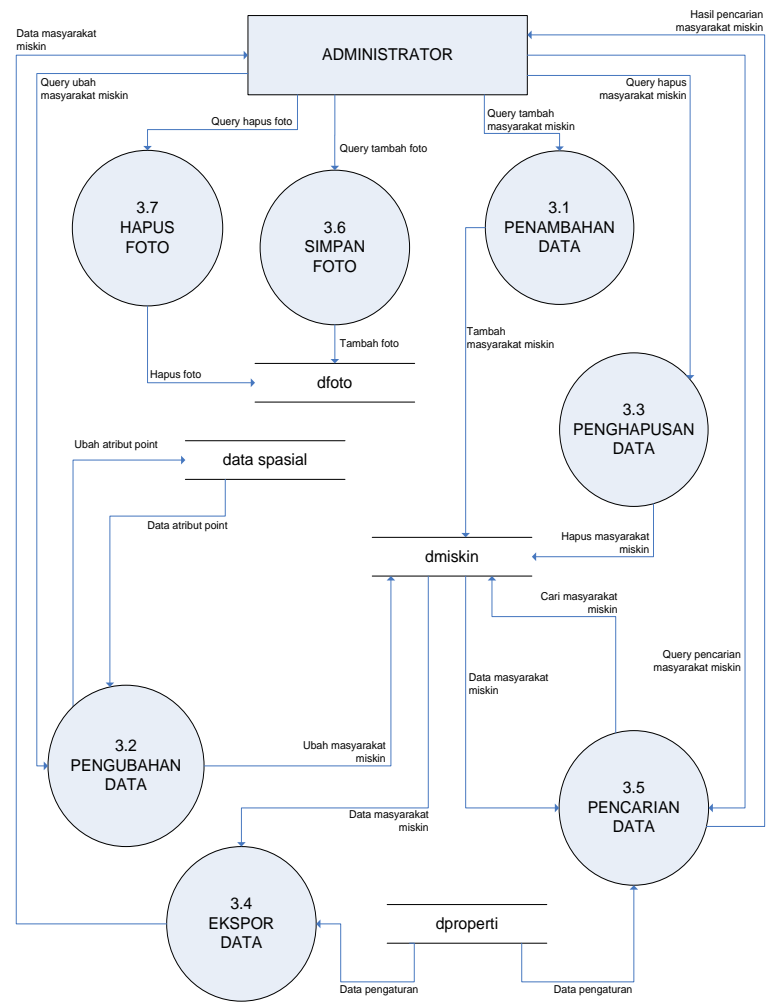

Gambar 10. Diagram rinci 3.0 manajemen masyarakat miskin

4. Proses 4.0 adalah proses manajemen penerima bantuan. Proses ini terbagi lagi menjadi 5 proses, diagram rinci Proses 4.0 diperlihatkan pada Gambar 11. 


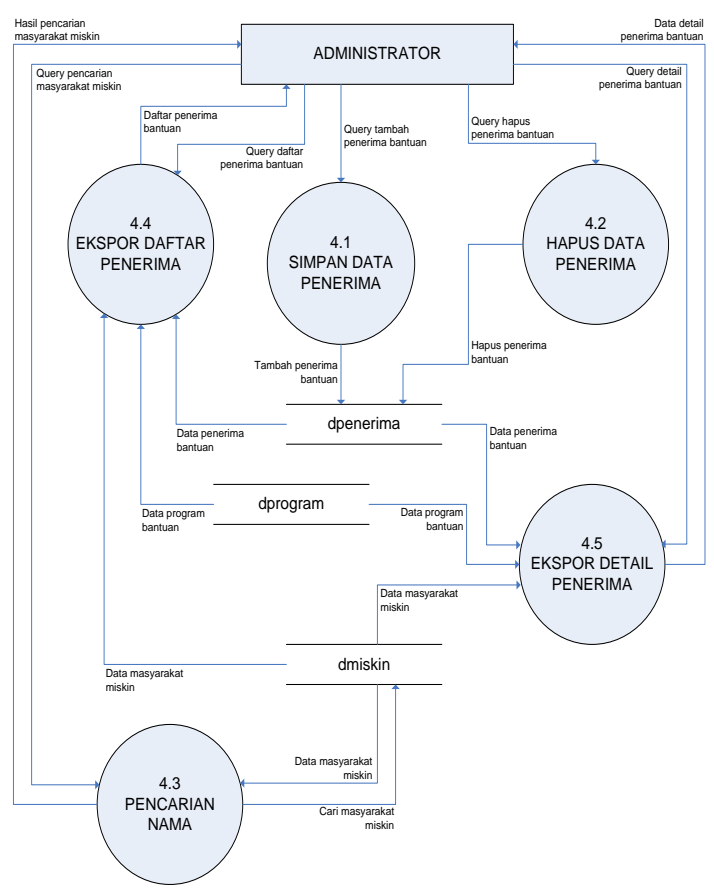

Gambar 11. Diagram rinci 4.0 manajemen penerima bantuan

\section{Perancangan Antarmuka Sistem}

Antarmuka yang dirancang pada aplikasi sistem informasi ini merupakan antarmuka untuk administrator dan user sekaligus, perbedaannya user tidak dapat melakukan perubahan apapun pada data. Aplikasi ini mempunya 5 (lima) menu utama yaitu peralatan peta (map tools), manajemen program bantuan, manajemen masyarakat miskin, manajemen penerima bantuan, dan rekaman penerima bantuan.

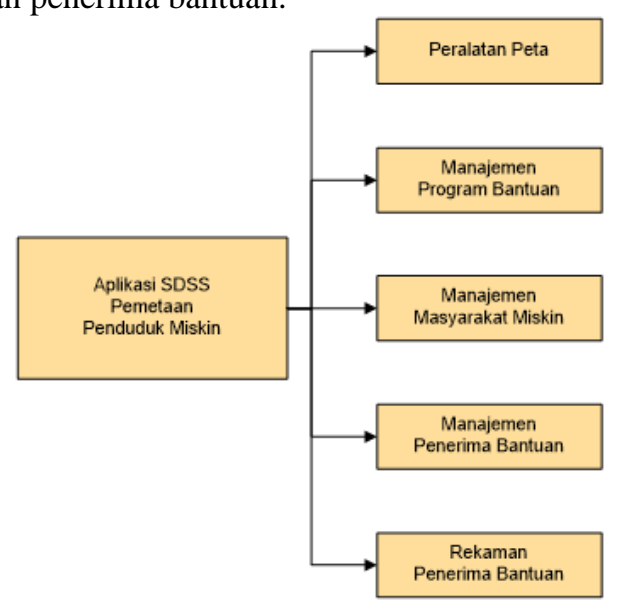

Gambar 12. Struktur menu aplikasi pemetaan penduduk miskin

\section{Layout Antarmuka}

Tataletak (layout) form utama antarmuka pengguna aplikasi dirancang dengan memperhatikan kemudahan pengguna, sebagaimana diperlihatkan pada Gambar 14.

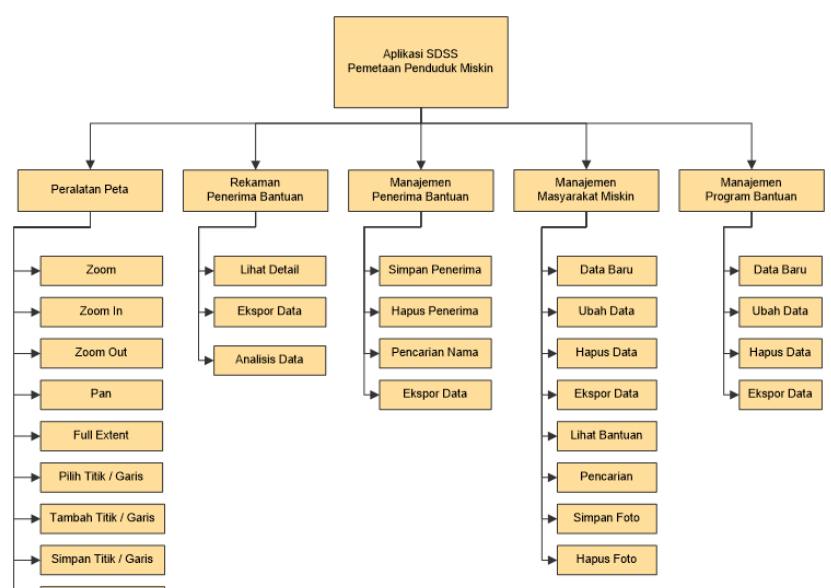

Gambar 13. Detail fungsi tiap menu

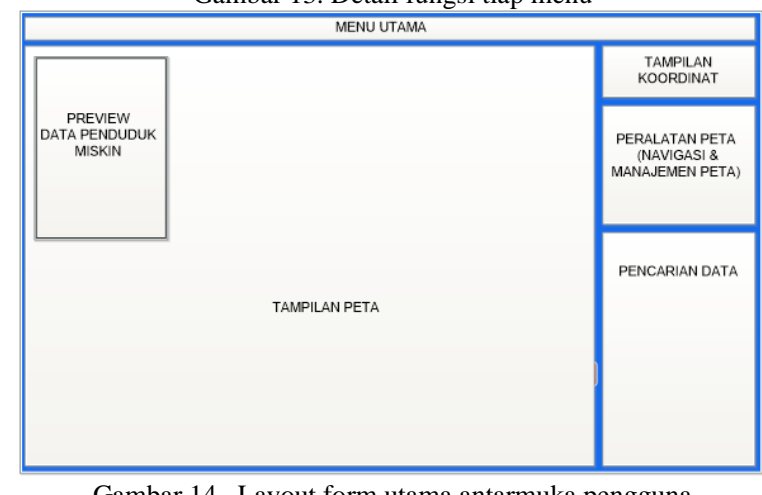

Gambar 14. Layout form utama antarmuka pengguna

\section{HASIL DAN ANALISIS}

Semua paragraf mesti di-indent. Semua paragraf mesti rata kiri dan rata kanan.

Dengan survey lapangan dan pengolahan data spasialnya maka keberadaan penduduk miskin ini dapat diketahui dengan tepat. Dengan diketahuinya lokasi tempat tinggal penduduk miskin memberikan kemudahan bagi pemerintah untuk merencanakan dan memberikan program-program pengentasan kemiskinan, di samping itu masyarakat dapat ikut serta dalam pengawasan pelaksaan program tersebut. Selain itu, masyarakat dapat memberikan bantuan secara langsung kepada penduduk miskin karena mengetahui keberadaan penduduk miskin disekitar tempat tinggalnya.

\section{A. Hasil Perancangan}

Hasil rancangan antara muka untuk Form Utama diperlihatkan pada Gambar 15. Pada bagian atas terdapat informasi dan peralatan peta. Pada bagian kiri terdapat menu-menu yang dapat digunakan oleh administrator. Pada bagian tengah terdapat Peta Kota Ketapang. Warna- 
warna yang berbeda pada peta menunjukkan wilayah administrasi yang berbeda.

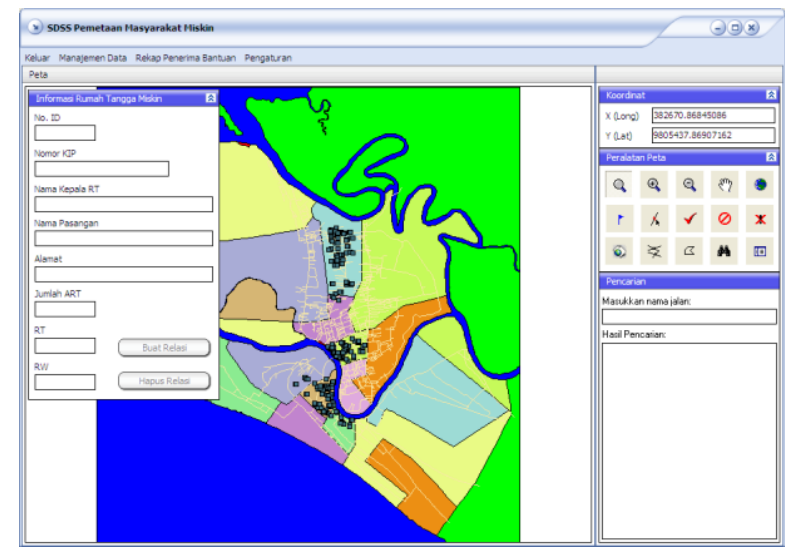

Gambar 15. Hasil rancangan form utama

Hasil rancangan Form Manajemen Kelurahan (Manajemen Data) diperlihatkan pada Gambat 16. Manajemen Kelurahan berfungsi untuk menambahkan data kelurahan serta mengubah, menghapus dan mengekspor data kelurahan yang sudah ada. Dalam pekerjaan ini terdapat 4 (empat) data kelurahan/desa yang diinputkan kedalam aplikasi yaitu Kelurahan Paya Kumang, Kelurahan Banjar, Kelurahan Tengah, dan Kelurahan Kauman.

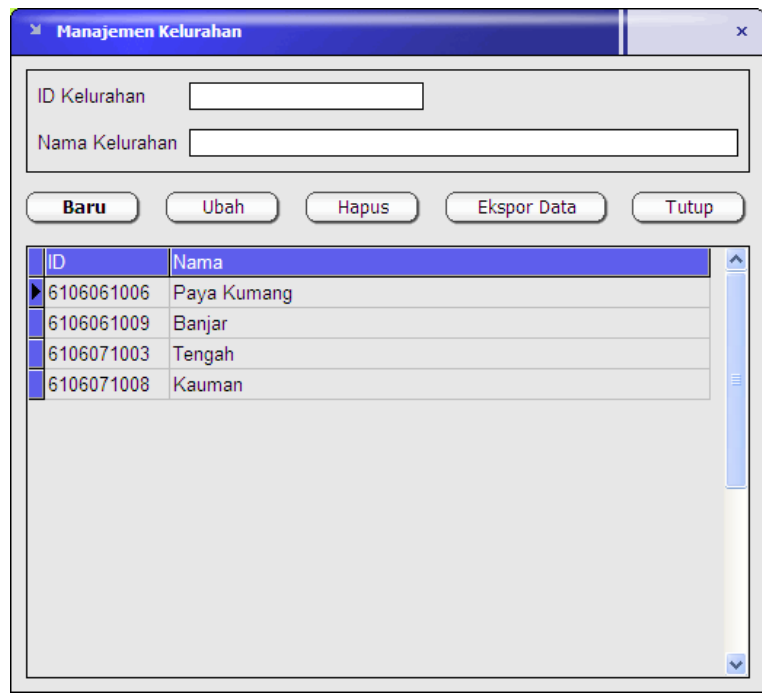

Gambar 16. Form Manajemen Kelurahan

Hasil rancangan Form Manajemen Program Bantuan (Program Pengentasan Kemiskinan) diperlihatkan pada Gambar 17. Manajemen Program Bantuan berfungsi untuk menambahkan program bantuan baru serta mengubah, menghapus dan meng-ekspor data program bantuan yang sudah ada.

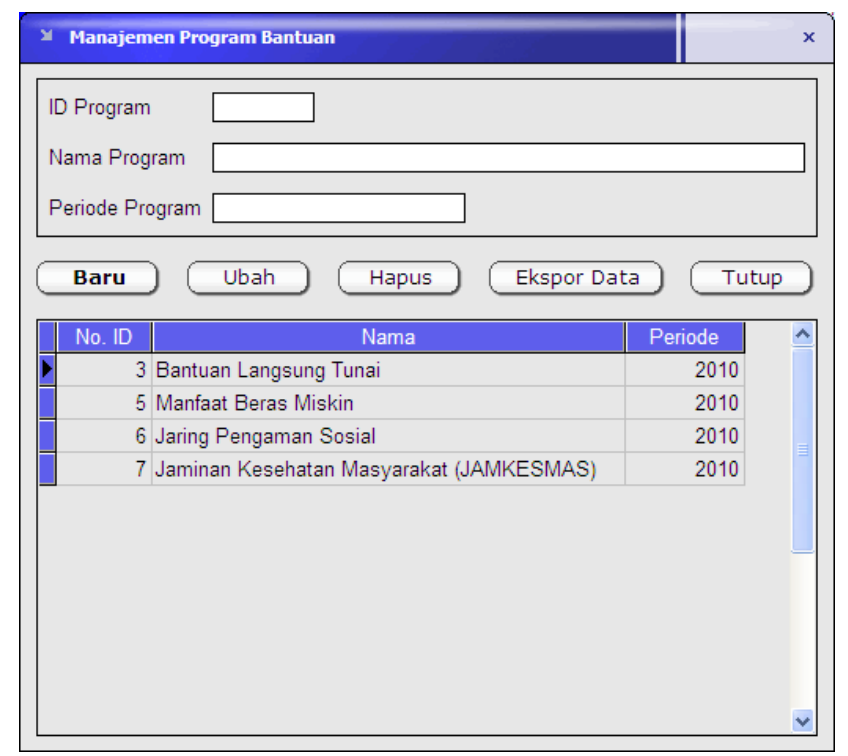

Gambar 17. Form Manajemen Program Bantuan

Hasil rancangan Form Manajemen Masyarakat Miskin sebagaimana terlihat pada Gambar 15 dan Gambar 16. Manajemen Masyarakat Miskin berfungsi untuk menambahkan data baru serta mengubah, menghapus dan meng-ekspor data yang sudah ada. Manajemen Masyarakat Miskin juga dapat digunakan untuk menyimpan dan menghapus foto. Pada Gambar 17 merupakan form manajemen masyarakat miskin untuk mengelola data atribut, sedangkan Gambar 18 merupakan form untuk mengelola data foto sebagai profil visualisasi dari masyaralat miskin.

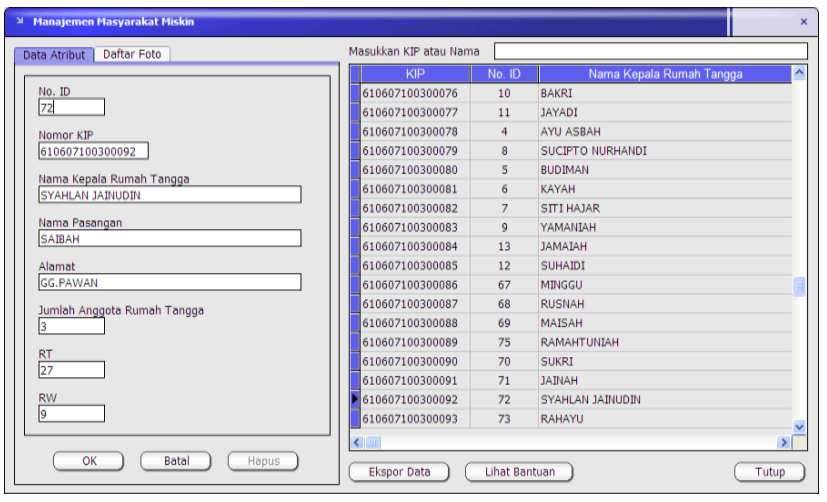

Gambar 18. Form manajemen masyarakat miskin (data atribut)

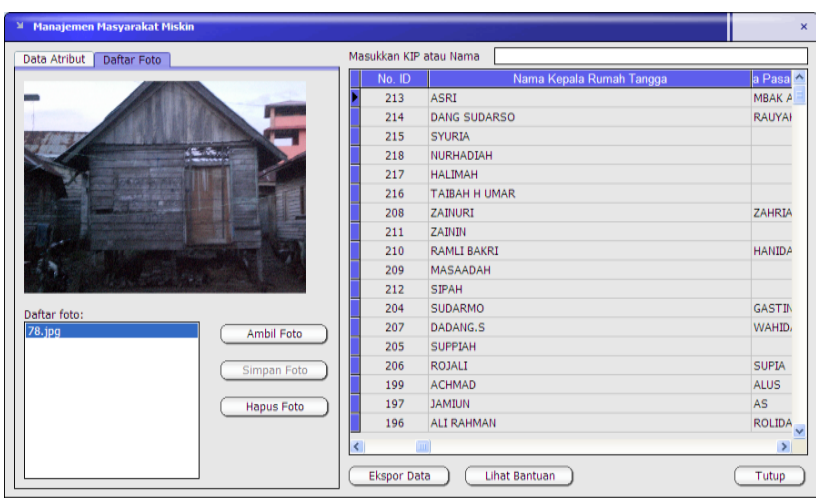

Gambar 19. Form masyarakat miskin (data foto) 
Hasil rancangan Form Manajemen Penerima Bantuan sebagaimana terlihat pada Gambar 20. Manajemen Penerima Bantuan berfungsi untuk memasukkan data baru penerima bantuan, serta menghapus dan meng-ekspor data penerima bantuan yang sudah ada.

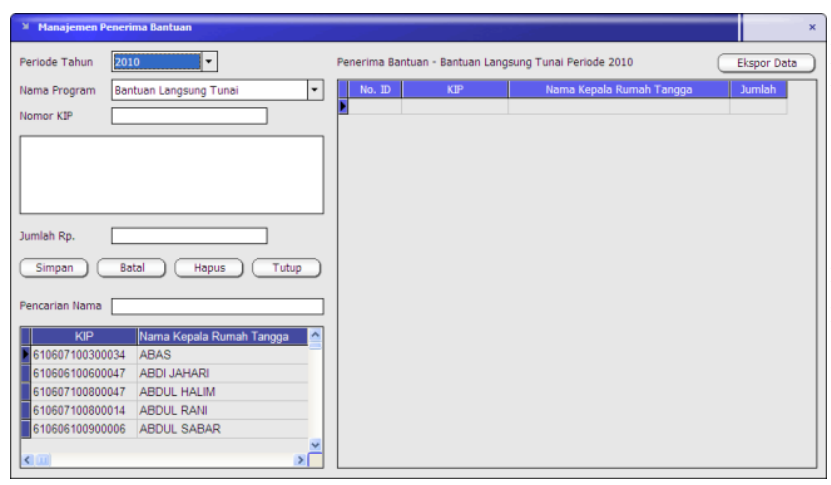

Gambar 20. Form manajemen penerima bantuan

Hasil rancangan Form Rekaman Penerima Bantuan sebagaimana terlihat pada Gambar 21. Manajemen Rekaman Penerima Bantuan berfungsi untuk menampilkan serta meng-ekspor data detail masyarakat miskin dan daftar bantuan yang diterima oleh masyarakat miskin.

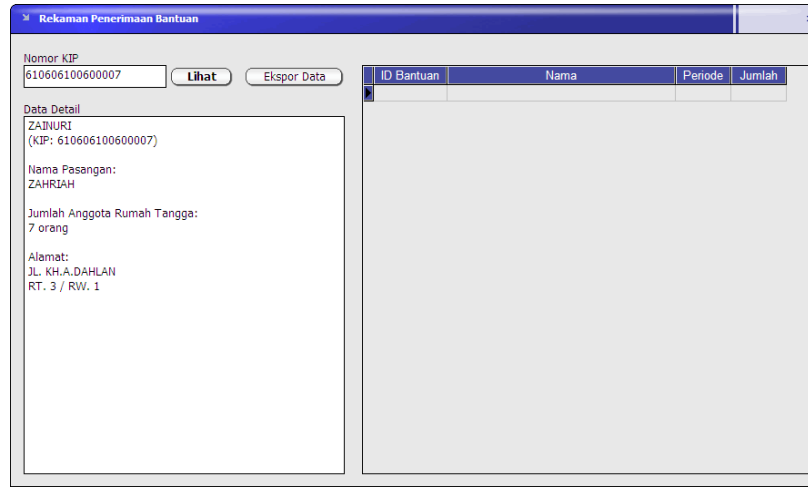

Gambar 21. Form Rekaman Penerima Bantuan

\section{B. Analisis Kinerja Aplikasi}

Berdasarkan analisa kebutuhan sistem, berikut ini adalah kinerja-kinerja yang dapat dilakukan oleh sistem informasi yang dirancang:

1. Sistem yang dirancang menggunakan database sesuai dengan keperluan dalam membangun sistem informasi geografis.

2. Sistem yang dirancang melakukan pengecekan terhadap data-data yang dimasukkan. Sistem akan memberikan pesan kepada pengguna jika pengguna memasukkan data-data yang salah, tidak lengkap atau kosong.

3. Pencarian/penelusuran data dengan data yang kosong akan menampilkan seluruh data yang ada. Ini sama halnya dengan tidak melakukan penelusuran. Pencarian data yang sesuai kata kunci akan menghasilkan data yang sesuai. Sedangkan pencarian dengan penggalan data akan menghasilkan data yang mengandung atau mempunyai kesamaan dengan kata kunci pada bagian data yang akan dicari.

Pengujian bertujuan untuk memeriksa apakah aplikasi dapat berjalan dengan baik sesuai dengan yang direncanakan berdasarkan nilai-nilai uji tiap proses yang dilakukan. Data pengujian dipilih berdasarkan spesifikasi masalah tanpa memperhatikan detail internal dari program. Pengujian dilakukan pada proses input data, pencarian, dan perubahan data.

\section{Input Data}

Input data adalah proses memasukkan data, dalam hal ini yaitu penginputan data-data program bantuan, masyarakat miskin dan penerima bantuan. Pengujian dilakukan dengan mengacu kepada semua kriteria yang ada pada form pengisian data.

1. Memasukkan data tidak bernilai (kosong) pada semua field di form isian,

2. Memasukkan data tidak bernilai (kosong) pada beberapa field di form isian,

3. Memasukkan data tidak bernilai sesuai / ekstrim, dan memasukkan data yang benar dan sesuai.

Pengujian pertama dilakukan dengan memasukkan data kosong pada semua isian, kemudian pengujian kedua dengan mengosongkan isian tahun. Pada kedua percobaan ini, aplikasi menampilkan pesan "Nama dan periode program tidak boleh kosong." seperti pada Gambar 22.

Pengujian ketiga dilakukan dengan memasukkan periode program yang tidak bernilai sesuai/ekstrim. Aplikasi menampilkan pesan "Periode program tidak valid." seperti pada Gambar 23. Pengujian keempat dilakukan dengan memasukkan semua data yang benar dan sesuai. Aplikasi memasukkan data tersebut ke dalam database, dan langsung menampilkan data baru tersebut.

Pengujian berikutnya adalah pengujian Input Data Masyarakat Miskin, pengujian pertama dilakukan dengan memasukkan data kosong pada semua isian, kemudian pengujian kedua dengan mengosongkan isian nomor KIP dan Jumlah Anggota Rumah Tangga. Pada kedua pengujian ini, aplikasi menampilkan pesan "Semua data kecuali No. ID tidak boleh kosong." seperti pada Gambar 4.23. Pengujian ketiga dilakukan dengan memasukkan jumlah anggota rumah tangga yang tidak bernilai sesuai/ekstrim. Aplikasi menampilkan pesan "Jumlah Anggota Rumah Tangga tidak valid." seperti pada Gambar 4.24. Pengujian keempat dilakukan dengan memasukkan semua data yang benar dan sesuai. Aplikasi memasukkan data tersebut ke dalam database, dan langsung menampilkan data baru tersebut. 


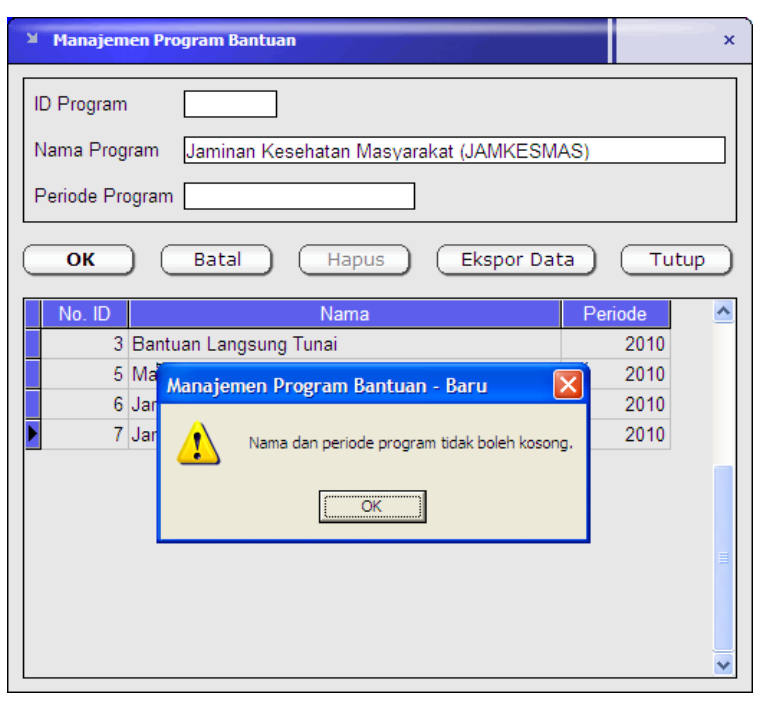

Gambar 22. Pesan yang muncul pada pengujian pertama dan kedua

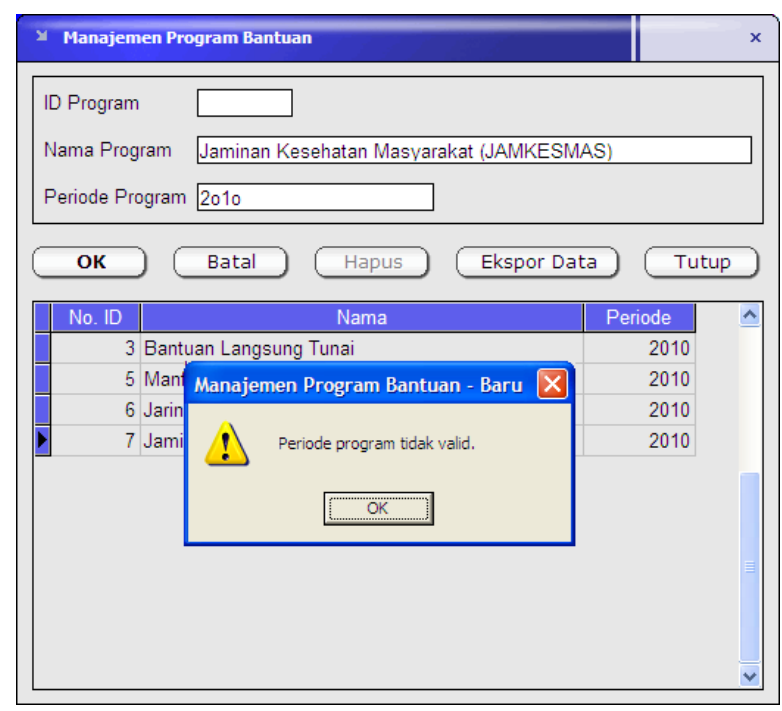

Gambar 23. Pesan yang muncul pada pengujian ketiga

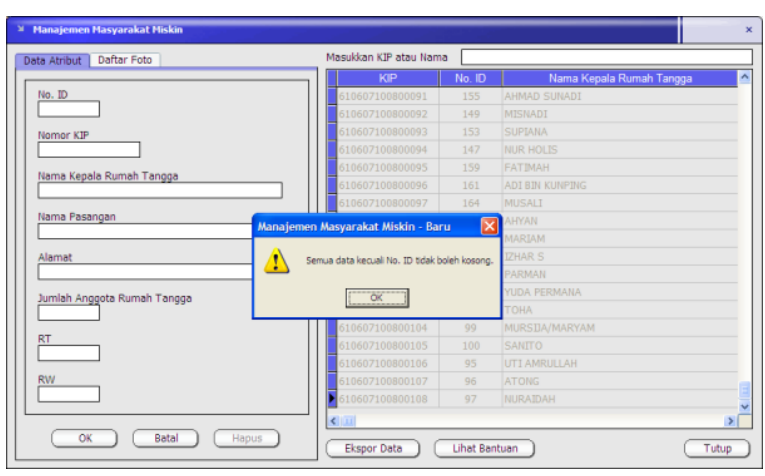

Gambar 24. Pesan yang muncul pada pengujian pertama dan kedua

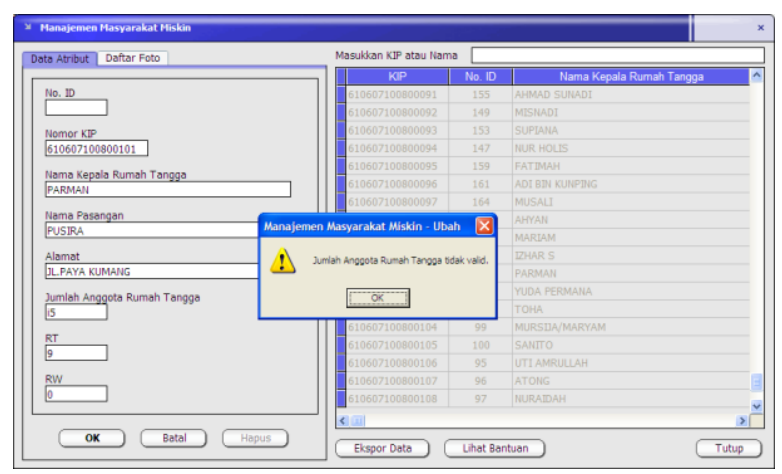

Gambar 25. Pesan yang muncul pada pengujian ketiga

Pengujian selanjutnya pada proses Input Data Penerima Bantuan. Pengujian pertama dilakukan dengan memasukkan data kosong pada semua isian. Aplikasi menampilkan pesan "Nomor KIP tidak valid." seperti pada Gambar 25. Pengujian kedua dilakukan dengan mengosongkan jumlah bantuan. Aplikasi menampilkan pesan "Jumlah bantuan tidak valid." seperti pada Gambar 26. Pengujian ketiga dilakukan dengan memasukkan jumlah bantuan yang tidak bernilai sesuai/ekstrim. Aplikasi menampilkan pesan "Jumlah bantuan tidak valid." seperti pada gambar. Pengujian keempat dilakukan dengan memasukkan semua data yang benar dan sesuai. Aplikasi memasukkan data tersebut ke dalam database, dan langsung menampilkan data baru tersebut.

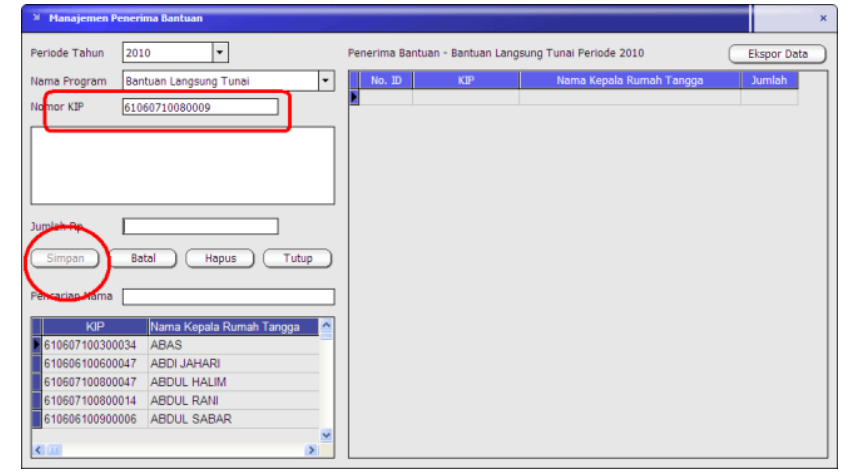

Gambar 26. Pesan yang muncul pada pengujian pertama

\section{Pencarian/Penelusuran Data}

Pencarian berfungsi untuk menampilkan data yang dibutuhkan. Dalam hal ini yaitu pencarian KIP atau nama pada Manajemen Masyarakat Miskin dan pencarian nama pada Manajemen Penerima Bantuan. Pengujian dilakukan dengan mengacu kepada semua kriteria yang ada pada bagian pencarian data.

1. Memasukkan data tidak bernilai (kosong) sebagai kata kunci,

2. Memasukkan data tidak bernilai sesuai / ekstrim sebagai kata kunci,

3. Memasukkan data yang benar dan sesuai sebagai kata kunci, dan

4. Memasukkan penggalan data yang benar dan sesuai sebagai kata kunci. 


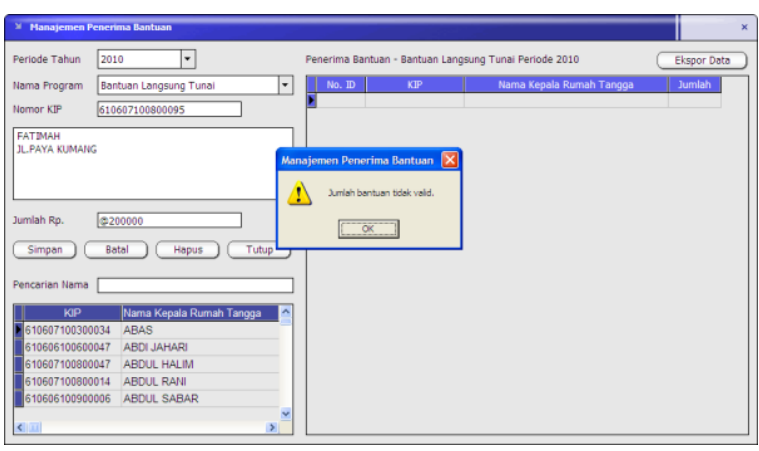

Gambar 27. Pesan yang muncul pada pengujian kedua dan ketiga

\section{E. Analisis Data Spasial}

Fitur analisis data spasial berfungsi untuk membantu pengguna dalam melakukan analisis data berdasarkan pilihan kriteria. Kriteria yang dapat dipilih adalah data penduduk miskin, data bantuan, dan jumlah anggota keluarga miskin. Data penduduk miskin dapat ditampilkan dengan 3 (tiga) pilihan yaitu tampilkan semua, hanya tampilkan yang pernah menerima, dan hanya tampilkan yang tidak pernah menerima. Gambar 28 dan Gambar 29 memperlihatkan contoh analisis data spasial berdasarkan penduduk miskin yang menerima bantuan dan penduduk miskin yang tidak pernah menerima bantuan.

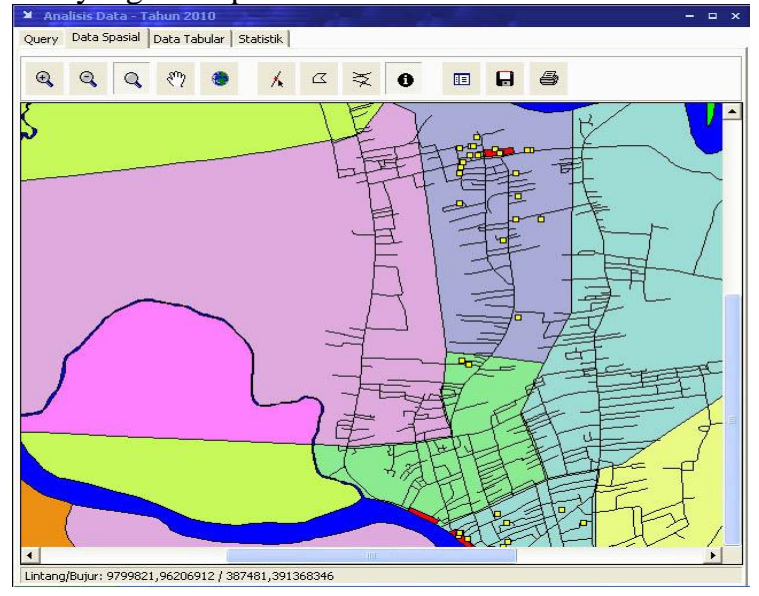

Gambar 28. Tampilan data spasial penduduk miskin dengan kriteria pernah menerima program bantuan kemiskinan

Berdasarkan Gambar 29 dapat diketahui bahwa masih terdapat beberapa penduduk miskin yang tidak pernah mendapat bantuan program kemiskinan, sementara penduduk miskin lain yang berada didekatnya mendapatkan program bantuan seperti terlihat pada Gambar 28. Beberapa hal yang mungkin terjadi antara lain terjadi perubahan data penduduk miskin namun tidak/belum dilakukan perubahan data atau telah terjadi penyelewengan dalam hal penyaluran bantuan kemiskinan.

Pada gambar selanjutnya yaitu Gambar 30 dan Gambar 31 memperlihatkan hasil analisis data yang menampilkan data yang lebih spesifik yaitu hanya menampilkan data penduduk miskin yang menerima bantuan dan penduduk miskin yang tidak menerima bantuan untuk program bantuan BLT (bantuan langsung tunai). Gambar 30 adalah gambar lokasi tempat tinggal penduduk miskin yang mendapat bantuan BLT dan Gambar 31 adalah gambar lokasi tempat tinggal penduduk miskin yang tidak mendapat bantuan BLT.

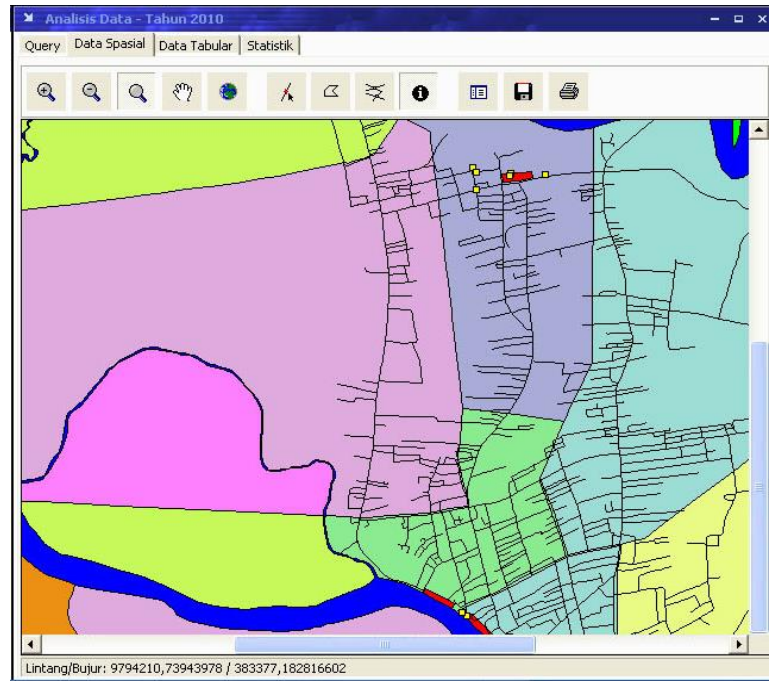

Gambar 29. Tampilan Data Spasial Penduduk Miskin dengan Kriteria Tidak Pernah Menerima Program Bantuan Kemiskinan

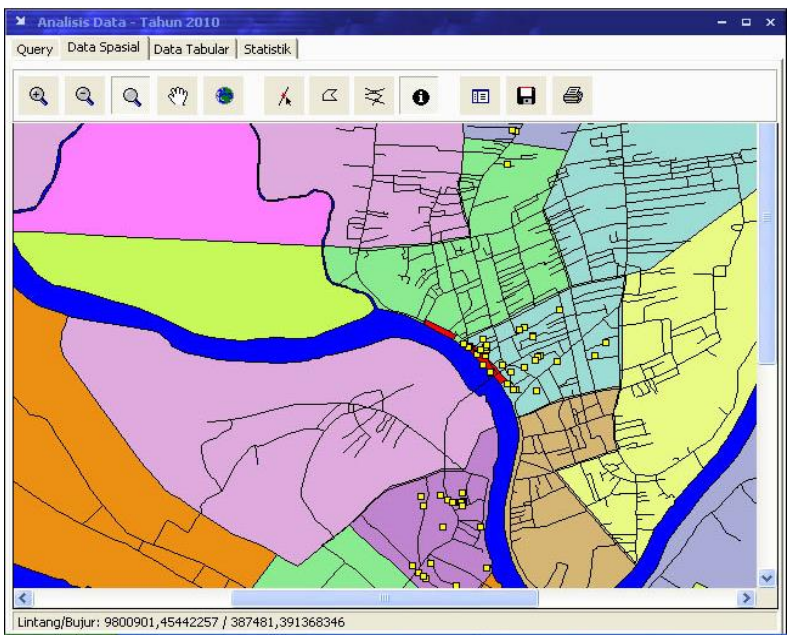

Gambar 30. Tampilan Data Spasial Penduduk Miskin yang Menerima BLT

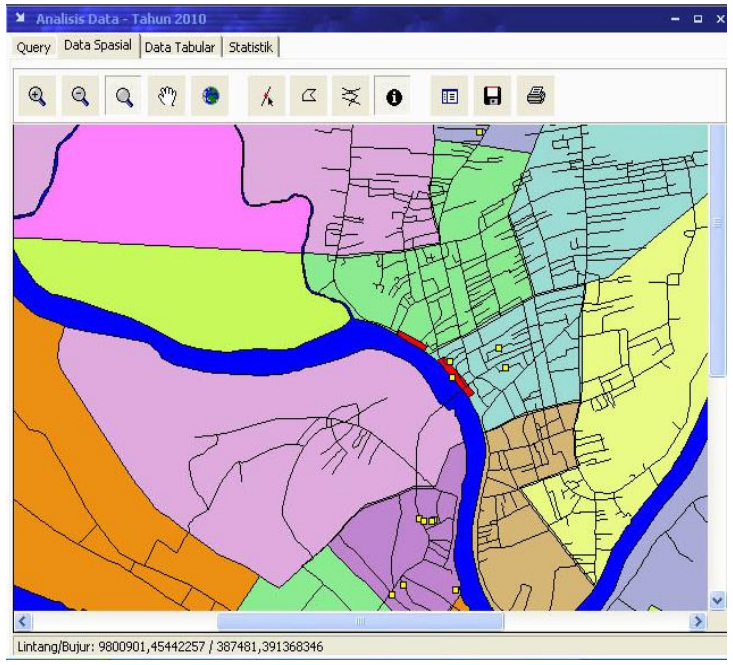

Gambar 31. Tampilan Data Spasial Penduduk Miskin yang Tidak Menerima BLT 
Analisis yang sama dapat dilakukan dari tampilan kedua gambar tersebut di atas, berdasarkan analisis ini pihak terkait khususnya pemerintah (dengan unsur terendah lurah atau kepala desa) dapat melakukan crosscheck ke lapangan apakah benar penduduk miskin yang tidak pernah mendapat bantuan (Gambar 28 dan Gambar 30) benar-benar ada (eksis) atau tidak, jika mereka benar-benar ada mengapa mereka tidak mendapatkan bantuan padahal mereka sudah didata dan masuk sebagai kategori penduduk miskin.

Representasi spasial seperti uraian di atas merupakan dukungan bagi pengambil keputusan (decision maker) untuk melakukan pengambilan keputusan (decision making) dalam upaya melaksanakan program pengentasan kemiskinan di Kota Ketapang. Unsur pemerintah terbawah (lurah/kepala desa) dapat berperan aktif untuk melakukan pendataan (collecting) dan pembaruan data (updating) penduduk miskin dalam wilayah kecil (small area) di wilayah tugasnya.

\section{KESIMPULAN}

1. Salah satu pendekatan alternatif untuk pengentasan kemiskinan adalah pendekatan spasial yang berbasis pada data pemetaan kemiskinan (poverty mapping). Dengan pendekatan ini data tempat tinggal penduduk miskin direpresentasi dengan simbol titik (point feature) dan direlasikan dengan data atribut atau data deskriptif sehingga pengelolaan dan akurasi data menjadi lebih baik.

2. Analisis spasial dilakukan pada wilayah administrasi yang kecil (small area) yaitu wilayah kelurahan/desa untuk mendapatkan profil penduduk miskin pada wilayah tersebut sehingga rekomendasi program kemiskinan dapat diberikan berdasarkan karakteristik pada wilayah yang dianalisis. Keputusan yang diambil berdasarkan dukungan analisis spasial dikenal dengan istilah spatial decision support system (SDSS).

3. Secara umum lokasi tempat tinggal penduduk miskin di Kota Ketapang berada di lokasi yang "tersembunyi" seperti di belakang perkantoran, ruko, atau tempat usaha lainnya termasuk di kawasan pinggiran/bantaran Sungai Pawan, akses menuju lokasi sedikit terhambat. Sementara di Desa Paya Kumang lokasi tempat tinggal penduduk miskin berada di jalan utama sehingga akses jalan lebih baik. Perbedaan kondisi kawasan di sekitar tempat tinggal penduduk miskin akan membedakan program pengentasan kemiskinan yang akan dilakukan.

4. Perangkat lunak aplikasi yang dikembangkan dalam pekerjaan ini ditujukan untuk kemudahan pengelolaan data penduduk miskin. Penanganan data historis yang terdapat pada aplikasi berguna untuk melakukan analisis berdasarkan tahun sehingga keberhasilan atau kegagalan program pengentasan kemiskinan dapat diketahui. Manajemen data atribut (data deskriptif) dilengkapi dengan foto untuk menyajikan informasi profil penduduk miskin secara lebih detil.

5. Proses perbaharuan (updating) data penduduk miskin dapat dilakukan berdasarkan wilayah masing-masing sampai ke tingkat kelurahan/desa. Proses updating dapat dilakukan sewaktu-waktu sesuai kebutuhan atau jika terjadi perubahan terhadap data. Dengan skenario ini biaya untuk proses updating data penduduk miskin dapat diefisienkan dan tingkat keakuratan data menjadi lebih baik karena proses updating dilakukan oleh petugas di kelurahan/desa.

\section{DAFTAR PUSTAKA}

[1] Bank Dunia, (2006). Making The New Indonesia Work For The Poor, The World Bank Office Indonesia, Jakarta.

[2] Davis, Benjamin., (2003). Choosing a Method for Poverty Mapping, Food and Agriculture Organization of The United Nations, Rome

[3] D. Desriyanti, Didik Riyanto, Prototype of Decision Support System Development in Determining Raskin Recipients Candidate, VOLT, Jurnal Ilmiah Pendidikan Teknik Elektro, 02 (2) (2017) 117-124.

[4] Desriyanti, Muslim, M. (2015). Sistem Pendukung Keputusan Pemberian Bantuan Masyarakat Miskin Menggunakan Metode Simple Additive Weighting (SAW). Prosiding SENATEK 2015 Purwokerto: Fakultas Teknik, Universitas Muhammadiyah Purwokerto

[5] Aa Zezen Zaenal Abidin, (2015), Konsepsi Sistem Pendukung Keputusan Spasial (Spatial Decision Support System) Untuk Bidang Pendidikan Berbasis Jaringan Data Spasial Nasional Dalam Rangka Perencanaan Pembangunan Pendidikan Nasional Secara Berklanjutan, Jurnal Teknologi Informasi dan Komunikasi, STMIK Subang, April 2015, ISSN: 2252-4517.

[6] Aronoff, Stan. (1989). Geographic Information Systems: A Management Perspective, WDL Publication, Ottawa-Canada.

[7] Dede Aprilia Haspita, Jimi Ali Baba, Decision Support System (Sistem Pendukung Keputusan) Penerimaan Peserta Didik Baru, Jurnal Manajemen Sistem Informasi dan Telematika (Telekomunikasi, Multimedia \& Informatika) Program Studi Teknik Informatika Fakultas Ilmu Komputer Universitas Bandar Lampung, Volume 10, Nomor 2, Oktober 2019 145-152

[8] Fitri Imansyah, (2019), Pemetaan Sebaran Data Buta Aksara Dengan Sistem Informasi Geografis Dan Database Engine, Jurnal Jepin ISSN(e): 2548-9364 / ISSN(p): 2460-0741

[9] Muhajir, Ahmad, Syamsinar, dan Ilham Alimuddin. (2005). Aplikasi SIG Dalam Pembuatan Sistem Informasi Data Kota Makassar. Surabaya, Indonesia: Institut Teknologi Sepuluh November.

[10] Suryahadi, Asep., Sudarno Sumarto, (2008). Efforts to Create a Small-Area Poverty Map in Indonesia, SMERU Newsletter, No.26 May-Aug/2008, SMERU Research Institute, Jakarta.

[11] Tata Sutabri, (2004), Analisa Sistem Informasi, Andi Offset, Yogyakarta.

[12] Sianturi, G., (2003). "Exit Strategy" Kemiskinan, www.gizi.net

[13] SMERU, (2008). The Poverty Map of Indonesia: Genesis and Significance, SMERU Newsletter No. 26: May-Aug/2008, SMERU Research Institute, Jakarta.

[14] L. Santos, J. Coutinho-Rodrigues, C.H. Antunes, A web spatia decision support system for vehicle routing using Google, Decision Support Systems 51(2011) 1-9.

[15] Malczewski, Jacek., (1997), Spatial Decision Support Systems, Department of Geography, University of Western Ontario, Canada. http://www.ncgia.ucsb.edu/giscc/

[16] Nuarsa IW, (2005), Belajar Sendiri Menganalisis Data Spasial Dengan Software GIS 3.3 untuk Pemula, Jakarta: PT Alex Media Computindo.

[17] Prahasta, Eddy, (2002), Konsep-konsep Dasar Informasi Geografis, Informatika, Bandung

[18] Murai, Shunji, (2006), GIS Workbook Vol I , University of Tokyo Diterjemahkan oleh Prayitno. 